\title{
KONFERENCIA-BESZÁMOLÓ
}

\section{A MAGATARTÁSORVOSLÁS SZEREPE A KÖZÉP-KELET-EURÓPAI HALÁLOZÁSI ÉS EGÉSZSÉGI KRÍZIS KUTATÁSÁBAN ÉS MEGELÓZÉSÉBEN}

- A konferencia idópontja: 2004. augusztus 30-31.

- Helyszíne: Semmelweis Egyetem, Nagyvárad téri Elméleti Tömb, 1089 Budapest, Nagyvárad tér 4.

- Fô szervezók: Selye János Magyar Magatartástudományi és Magatartásorvoslási Társaság, Semmelweis Egyetem, Magatartástudományi Intézet

- További szervezók: International Society of Behavioural Medicine, United Nations Developmental Programmes (UNDP), Végeken Alapítvány, AEP Section of Epidemiology and Social Psychiatry Group April 2002

A konferencia a Mainzban 2004. augusztus 24-28. között zajló Nemzetközi Magatartásorvoslási Konferencia szatellit rendezvénye volt, valamint négy, a témával foglalkozó United Nations Development Programme (UNDP) pályázat záróülése, a jelenleg folyó „Európai szövetség a depresszió ellen" európai keretprogram (EAAD) munkamegbeszélése és a WHO 2005-ös, a lelki egészség jelentôségét áttekintô konferenciájának elókészítố ülése.

A konferencia célja elsősorban az intenzív párbeszéd, együttmúködés és gyakorlati ajánlások megfogalmazása volt a nemzetközi, hazai és a régiónkból érkező kutatók, egészségpolitikusok és klinikusok közremúködésével. A találkozón 21 országból 146-an vettek részt, 109 résztvevő Közép- és Kelet-Európából (Bulgária, Lengyelország, Magyarország, Örményország, Románia, Szlovákia).

Az elsố nap áttekintố előadásain és vitacsoportjain olyan nemzetközi hírú kutatók vettek részt, mint Lennart Levi, a Karolinska Egyetem Pszichoszociális Intézetének megalapítója, Brian Oldenburg, Antti Uutela, Neil Schneiderman és Edwin Fisher, a leghatékonyabb ausztrál, finn és amerikai közösségi alapú magatartásorvoslási megelózési programok vezetói, Johannes Siegrist, a munkastressz elméletek megalapozója, Redford 
Williams, a depresszió genetikai és pszichoszociális összefüggéseinek kutatója, valamint Martin Bobak, a Whitehall Study egyik vezetóje.

A második nap kilenc intenzív témacsoportja a következő volt: 1 . egészségfejlesztó programok, 2. kardiovaszkuláris megbetegedések, 3. önkárosító magatartásformák: öngyilkosság, alkohol és drog, 4. a megelőzés finanszírozása, 5. közösségi alapú programok, 6. krónikus megbetegedések pszichoszociális aspektusai, 7. szociális-gazdasági helyzet és egészség, 8. gyermekek és a család egészsége, 9. időskor: az idősek egészsége és életminósége.

A témacsoportok vezetói olyan nemzetközileg elismert szakemberek voltak, mint John Barefoot, az ellenségesség szív-érrendszeri hatásainak leírója, vagy Linda Bauman, a harmadik világ legeredményesebb cukorbetegség elleni programjainak vezetôje.

\section{A KONFERENCIA EREDMÉNYEI}

A konferencia alapvetố célja a régiónkban az utóbbi évtizedekben tapasztalt halálozási és egészségi krízis okainak vizsgálata és az egészségfejlesztés lehetôségeinek megbeszélése volt. Ez a jelenség rendkívüli kihívás az orvostudomány, a népegészségügy és az egészségpolitika számára egyaránt. A konferencia a legkiválóbb nemzetközi és hazai szakemberek közremúködésével azt vizsgálta, hogy mi lehet az oka, hogy míg az 1960as években régiónkban viszonylag jók voltak az egészségi mutatók, addig ma a középkorú férfiak halálozása magasabb, mint az 1930-as években volt. Annak valószínúsége, hogy egy férfi túléli a 65. életévét Magyarországon ma csupán 59\%, ez az arány Ausztriában 80\%. A középkorú nók idố elótti halálozása is háromszor magasabb, mint az európai átlag. Mit tehetünk ezeknek a tragikus jelenségeknek a változtatására?

A magatartásorvoslás olyan multidiszciplináris megközelítést jelent, amely a genetika, élettan, szomatikus orvostudomány ismereteit ötvözi a pszichológiai, népegészségügyi, szociológiai, antropológiai eredményekkel. A régiónkban tapasztalható egészségi krízis hátterében a krónikus stressz és az azzal való megbirkózási készségek elégtelensége alapvetô. Míg az objektív mutatók (gének, életkor, nem) hatásait igen nehéz befolyásolni, a stresszel való megbirkózás készségei erősíthetőek - ennek bizonyítottan hatékony módszereit tárgyalta a konferencia.

Gyakorlati eredményként Közép-Kelet-Európai Magatartásorvoslási Hálózat alakult meg, amely következó összejövetelét 2005 nyarán Kolozsvárott tartja. A Hálózat célja a magatartásorvoslási oktatás, kutatás és gyakorlati egészségfejlesztési módszerek bevezetése és erôsítése a régió 
országaiban, az egészségromlás okainak feltárása és lehetôség szerinti megelózése céljából. Mint ahogyan Finnországban egy hasonló egészségi krízis hatására a „Mentsük meg a férfiakat!” mozgalom országos céllá vált, hasonló mozgalmak szervezése a Hálózatnak is fontos célkitúzése. Munkája során a Hálózat támaszkodni kíván a civil társadalom, a tömegtájékoztatás és az egészségfejlesztés ügyéért tenni kívánó személyek és csoportok minél szélesebb körú bevonására. Mivel az egészségi krízis a leszakadó rétegekben a legsúlyosabb, különösen itt van szükség sürgós lépésekre. A civil szervezetek közül az önkéntes kölcsönös egészségpénztárak, a foglalkozás-egészségügyi hálózat, a kisebbségi önkormányzatok és a munkanélkülieket támogató alapítványok szerepe alapvetô a tervezett közösségi alapú egészségfejlesztési programok megvalósításához, amelyhez a bizonyítottan hatékony nemzetközi programok tapasztalatait és módszereit vesszük alapul. Nagyon reméljük, hogy a Hálózat komolyan hozzájárulhat a társadalmi tóke oly szükséges erősítéséhez régiónkban. A Hálózat honlapja egyelóre a www.selyesociety.org, elektronikus leveleket az info@selyesociety.org címre várunk.

Dr. Kopp Mária

Semmelweis Egyetem, Magatartástudományi Intézet 1089 Budapest, Nagyvárad tér 4.

E-mail: kopmar@net.sote.hu 